\title{
Acute myeloid leukemia in older adults
}

\author{
Masamitsu Yanada $\cdot$ Tomoki Naoe
}

Received: 31 May 2012/Revised: 25 June 2012/Accepted: 26 June 2012/Published online: 13 July 2012

(c) The Japanese Society of Hematology 2012

\begin{abstract}
Acute myeloid leukemia (AML) is predominantly a disease of older adults, with a median age at diagnosis of over 65 years. AML in older adults differs biologically and clinically from that in younger ones, and is characterized by stronger intrinsic resistance and lower tolerance to chemotherapy. The effects of age on both patient- and disease-related factors result in a higher incidence of early death during chemotherapy, a lower rate of complete remission, and a reduced chance of long-term survival. Treatment options for older adults with AML include intensive chemotherapy, less-intensive chemotherapy, best supportive care, or enrolment in clinical trials. Given the heterogeneous nature of AML in older adults, therapeutic decisions need to be individualized after systematic assessment of disease biology and patient characteristics. Regardless of treatment, however, outcomes for older AML patients remain in general unsatisfactory. In contrast with the progress made for younger adults, the treatment of AML in older adults has not improved significantly in recent decades. Development of less toxic and more targeted agents may well provide treatment alternatives for a majority of these patients. The overall dismal outcome with currently available treatment approaches has encouraged older AML patients to participate in prospective clinical trials.
\end{abstract}

\section{Yanada $(\bowtie)$}

Department of Hematology,

Fujita Health University School of Medicine,

1-98 Dengakugakubo, Kutsukake-cho,

Toyoake 470-1192, Japan

e-mail: myanada@fujita-hu.ac.jp

T. Naoe

Department of Hematology and Oncology,

Nagoya University Graduate School of Medicine, Nagoya, Japan
Keywords Acute myeloid leukemia - Older adults · Elderly AML · Chemotherapy · Targeted therapy

\section{Introduction}

Acute myeloid leukemia (AML) is a disease that primarily affects older adults, and the median age at diagnosis is over 65 years [1-3]. The cut-off age for differentiating younger from older AML is arbitrary; age 65 or older has traditionally been used as the eligibility criterion for previous studies of elderly AML by the Japan Adult Leukemia Study Group, whereas other study groups have chosen, among others, 60 or older, 70 or older, or 50-70 years. For practical purposes, however, age 60 or over is generally used to define elderly AML $[4,5]$. Elderly AML is a biologically and clinically distinct disease with a diminished response to chemotherapy. Previous clinical trials of intensive chemotherapy showed rates of complete remission (CR) around $50 \%$ and of longterm survival at less than $10 \%$, which are much worse than for younger patients [1-3]. Furthermore, such data likely overestimate the true outcome for elderly AML, as patients entered into clinical trials are screened using criteria such that they often do not represent the general patient population. In contrast with the progress made for younger adults, the outcome of treatment of elderly AML has improved little, if at all, in recent decades [6,7]. The adverse prognostic impact of older age is attributable to differences both in disease-related factors (i.e., cytogenetics, secondary AML, and expression of the multidrug resistance phenotype) and patient-related factors (i.e., general condition, organ dysfunctions, and comorbidities). In addition to these therapeutic drawbacks, the net incidence of elderly AML is expected to increase as the population continues to age, making the management of elderly AML an even more critical issue. 


\section{Characteristics of AML in older adults}

The unfavorable biologic characteristics of AML amplified in older adults, such as a higher proportion of unfavorable cytogenetics, higher frequency of antecedent hematologic disorders or previous treatment for one or more other malignancies, and more frequent expression of the multidrug resistance phenotype. Cytogenetic findings at diagnosis have important prognostic implications for both younger and older patients [8-10]. Favorable cytogenetic characteristics, e.g., core binding factor (CBF) abnormalities as defined by $t(8 ; 21)$ or inv $(16) / t(16 ; 16)$, are relatively uncommon in older adults, and are seen in less than $5 \%$ of patients aged over 60 years [8-10]. In contrast, unfavorable cytogenetics represented by complex karyotype is predominant in older patients. Secondary AML arising from myelodysplastic syndrome (MDS) or myeloproliferative neoplasm (MPN), or AML related to prior chemotherapy for previous malignancies, both of which are known as subtypes with increased resistance to chemotherapy, is also common in this age group [1-3]. Response to chemotherapy is affected by the expression of genes that confer drug resistance, such as the multidrug resistance 1 (MDR1) gene that encodes the chemotherapy efflux pump P-glycoprotein. Overexpression of P-glycoprotein reportedly occurs in $71 \%$ of older patients, compared to only $35 \%$ of younger patients [11].

Patient-related factors, such as poor general condition, significant comorbidities, and diminished functional reserves, also contribute to the poorer outcomes for older patients. Moreover, because of their reduced performance status (PS) and increased prevalence of significant comorbidities, older patients are less tolerant of complications associated with chemotherapy. These conditions often make physicians reluctant to administer intensive chemotherapy to older patients. Indeed, according to a survey conducted in the United States, chemotherapy was administered to only $30 \%$ of patients over the age of 65 years [12]. Although selected patients can tolerate and benefit from intensive chemotherapy, older adults as a whole are more likely to experience treatment-related mortality (TRM) and less likely to benefit from standard induction and post-remission therapies.

Taken together, these findings indicate that the effects of age in terms of both patient- and disease-related factors result in a higher incidence of early death during induction therapy, a lower rate of $\mathrm{CR}$, and a reduced chance of longterm survival.

\section{Prognosis and prognostic factors}

The prognosis of AML worsens with age. When treated with intensive chemotherapy, CR rates for older adults range between 40 and $60 \%$ [1-3], which is much lower than those for younger adults. Even if CR is achieved, older adults are more likely to experience relapse, leading to an extremely low expectation for long-term survival. Such a poor chance of treatment success is combined with a high risk of TRM, which ranges from 10 to $40 \%$ even for selected older adults [1-3].

Because of intrinsic resistance to chemotherapy and excessive toxicity, the benefits associated with standard chemotherapy for older adults remain debatable. Since these patients represent a heterogeneous population, it is clinically important to identify those who are and are not likely to benefit from standard chemotherapy. This medical requirement has prompted the generation of several prognostic models incorporating multiple covariates (Table 1) [13-17]. These systems may help determine whether a patient should receive standard chemotherapy or alternative treatment. Among the most important prognostic factors are age, cytogenetics, and PS. In addition, some recent studies have shown genetic mutations involving the fmslike tyrosine kinase 3 (FLT3) gene, the nucleophosmin 1 (NPM1) gene, and others are as prognostically relevant for older as they are for younger patients [18-21], while other studies have shown that gene expression profiles can identify prognostically distinct subgroups $[22,23]$. These recent findings nonetheless need to be validated before they can be adopted for therapeutic decision-making.

The PS classification is commonly used for assessing whether or not a patient is fit for intensive chemotherapy $[4,5]$. However, this classification may be suboptimal, as it does not differentiate between functional impairments resulting from leukemia and those resulting from unrelated comorbidities. This distinction is important, as the former can be reversible with treatment, while the latter are not. In this respect, comorbidity scoring rather than PS assessment may be a potentially more accurate basis for therapeutic decisions [24].

\section{Treatment}

Induction therapy

Since a randomized study reported by Lowenberg et al. [25] in 1989 demonstrated that intensive chemotherapy could change the natural history of AML in elderly patients, induction therapy has been considered a viable option in the management of elderly AML. A recent population-based study in Sweden indicates that this may also be the case with unselected patients [26]. Another retrospective study using a propensity score matching analysis suggests that intensive chemotherapy has a beneficial effect on OS even for patients aged 70 years or older [27]. 
Table 1 Covariates constituting predictive models for overall survival in older adults with AML

\begin{tabular}{ll}
\hline Study & Covariates \\
\hline $\begin{array}{c}\text { Kantarjian } \\
\text { et al. [13] }\end{array}$ & Age $(65-74$ or $\geq 75$ years $)$, cytogenetics, PS, AHD, \\
Frohling et al. & Age (61-69 or $\geq 70$ years), cytogenetics \\
[14] & \\
Malfuson et al. & Age (65-74 or $\geq 75$ years), cytogenetics, PS, WBC \\
{$[15]$} & \\
Wheatley et al. & Age $(60-64,65-69,70-74$ or $\geq 75$ years $)$, \\
{$[16]$} & cytogenetics, PS, WBC, secondary leukemia \\
Rollig et al. & Age $(61-65$ or $\geq 66$ years), WBC count, LDH, \\
{$[17]^{\text {a }}$} & CD34 expression, NPM1 mutation
\end{tabular}

$P S$ performance status, $A H D$ antecedent hematologic disorder, $L D H$ lactate dehydrogenase, $W B C$ white blood cell, NPM1 nucleophosmin 1

${ }^{\text {a }}$ Only patients with cytogenetically intermediate risk were analyzed

The standard induction therapy consists of an anthracycline combined with cytarabine (AraC), known as " $3+7$ ", a regimen that has been the mainstay for more than three decades. For selected patients, standard induction therapy yields CR rates of around $50 \%$ [1-3]. As shown in Table 2, a multitude of attempts have been made in the hope of improving the outcome, such as escalating doses, replacing or adding drugs, and using growth factors [25, 28-47], but most if not all failed to demonstrate survival benefit. However, a number of studies have reported positive results. Schlenk et al. [34] evaluated the effect of all-trans retinoic acid (ATRA) administered in combination with induction and consolidation therapy to 242 patients more than 60 years old. They showed that addition of ATRA significantly improved CR rate, event-free survival (EFS) and overall survival (OS). Lowenberg et al. [41] compared the effect of a doubled dose of daunorubicin (DNR) of $90 \mathrm{mg} / \mathrm{m}^{2}$ with that of a conventional dose of $45 \mathrm{mg} / \mathrm{m}^{2}$ in the context of the " $3+7$ regimen" administered to 813 patients aged 60 or older. Although no overall difference in outcome was observed, patients who were between 60 and 65 years old significantly benefited from the doubled dose of DNR. Very recently, Castaigne et al. [46] reported results from a phase 3 study that examined the effect of adding gemtuzumab ozogamicin (GO). In their study, a total of 280 patients aged 50-70 were randomly assigned to receive GO or a placebo in combination with chemotherapy during induction and consolidation courses. While CR rates for the two arms were not different, GO significantly improved relapse-free survival (RFS), EFS, and OS. Since none of these positive results have as yet been reproduced elsewhere, definitive conclusions regarding the effectiveness of these treatments await the results of further validation studies.
For patients unfit for intensive chemotherapy, treatment options include less-intensive chemotherapy, best supportive care, or enrolment in clinical trials. For lessintensive chemotherapy, low-dose AraC has been utilized since the 1960s. Burnett et al. [37] recently demonstrated in a phase 3 study that low-dose AraC significantly prolonged OS when compared to best supportive care for older patients who were considered unfit for intensive chemotherapy. Stratification by cytogenetic risk made it clear that low-dose AraC was beneficial for patients with favorable and intermediate cytogenetic risks. Despite the significant superiority of low-dose AraC over best supportive care, outcome with low-dose AraC remained far from satisfactory, as the probabilities of CR and 1-year OS were only 18 and $25 \%$, respectively [37].

\section{Post-remission therapy}

Once CR has been reached after induction therapy, however, there is no standard post-remission strategy for elderly AML. Table 3 summarizes selected randomized studies using post-remission therapy $[30,31,36,38,40,43$, 47-51]. None of these studies have shown improved survival resulting from treatment intensification: increasing the dose of AraC did not result in better outcome when compared to the standard dose [48], and results for four cycles of consolidation therapy were not superior to those for three cycles [40], or even for a single cycle [31]. However, prolonged therapy with lower doses of chemotherapy may be beneficial for elderly patients. Gardin et al. [36] compared consolidation therapy consisting of six lessintensive courses administered monthly on an outpatient basis with one course of intensive chemotherapy. After achieving CR, 164 patients aged 65 years or older were randomized to either the outpatient or intensive arm, with the former showing significantly superior DFS and OS. In addition to this finding, several studies showed the beneficial effect of prolonged maintenance therapy for the prevention of relapse, although they did not show significant survival advantage [30, 49]. On the other hand, Schlenk et al. [50] reported that one course of intensive consolidation chemotherapy was superior to one year of oral maintenance therapy in terms of relapse prevention and OS. The reason for this discrepancy is unclear, but may be partly explained by differences in treatment regimens used in these studies. Older adults are highly likely to be unable to complete or even start planned post-remission therapy because of comorbidities or residual toxicities from previous chemotherapy. Hence, special consideration needs to be given to the feasibility of treatment when considering post-remission therapy for older adults. 
Table 2 Selected randomized studies using induction therapy for AML in older adults

\begin{tabular}{|c|c|c|c|c|}
\hline Study & $\begin{array}{l}\text { Age } \\
\text { (years) }\end{array}$ & $N$ & Treatments & Results \\
\hline $\begin{array}{l}\text { Lowenberg } \\
\text { et al. [25] }\end{array}$ & $>65$ & $\begin{array}{l}31 \\
29\end{array}$ & $\begin{array}{l}\text { DNR, AraC, VCR } \\
\text { Supportive care }\end{array}$ & $\begin{array}{l}\text { Compared to supportive care, intensive chemotherapy prolonged OS without } \\
\text { increasing hospitalization time }\end{array}$ \\
\hline $\begin{array}{l}\text { Tilly et al. } \\
\text { [28] }\end{array}$ & $>65$ & $\begin{array}{l}46 \\
41\end{array}$ & $\begin{array}{l}\text { RBX, AraC } \\
\text { Low-dose AraC }\end{array}$ & $\begin{array}{l}\text { Intensive chemotherapy increased both CR and early death rates, resulting in } \\
\text { OS similar to that for low-dose AraC }\end{array}$ \\
\hline $\begin{array}{l}\text { Lowenberg } \\
\text { et al. [29] }\end{array}$ & $>60$ & $\begin{array}{l}161 \\
157\end{array}$ & $\begin{array}{l}\text { DNR, AraC } \\
\text { DNR, AraC, GM-CSF }\end{array}$ & $\begin{array}{l}\text { GM-CSF during and after induction therapy did not improve CR rate DFS or } \\
\text { OS }\end{array}$ \\
\hline $\begin{array}{l}\text { Lowenberg } \\
\text { et al. [30] }\end{array}$ & $>60$ & $\begin{array}{l}242 \\
247\end{array}$ & $\begin{array}{l}\text { DNR, AraC } \\
\text { MIT, AraC }\end{array}$ & $\begin{array}{l}\text { CR rate tended to be higher with MIT, but DFS and OS did not differ for the } \\
\text { two arms }\end{array}$ \\
\hline $\begin{array}{l}\text { Goldstone } \\
\text { et al. [31] }\end{array}$ & $>55$ & $\begin{array}{l}328 \\
327 \\
656\end{array}$ & $\begin{array}{l}\text { DNR, AraC, } 6 \mathrm{TG} \\
\text { DNR, AraC, ETP } \\
\text { MIT, AraC }\end{array}$ & $\begin{array}{l}\text { Neither addition of ETP nor replacement of DNR with MIT contributed to } \\
\text { improvement in CR rate or OS }\end{array}$ \\
\hline $\begin{array}{l}\text { Anderson } \\
\text { et al. [32] }\end{array}$ & $>55$ & $\begin{array}{l}161 \\
167\end{array}$ & $\begin{array}{l}\text { DNR, AraC } \\
\text { MIT, ETP }\end{array}$ & $\begin{array}{l}\text { Results in terms of CR rate, RFS or OS for induction therapy with MIT and } \\
\text { ETP were not superior to those for DNR and AraC }\end{array}$ \\
\hline $\begin{array}{l}\text { Baer } \\
\text { et al.[33] }\end{array}$ & $\geq 60$ & $\begin{array}{l}61 \\
59\end{array}$ & $\begin{array}{l}\text { DNR, AraC, ETP } \\
\text { DNR, AraC, ETP, PSC-833 }\end{array}$ & $\begin{array}{l}\text { Addition of the P-glycoprotein modulator PSC- } 833 \text { did not increase CR rate, } \\
\text { DFS or OS, but was associated with excessive early mortality }\end{array}$ \\
\hline $\begin{array}{l}\text { Schlenk } \\
\text { et al. [34] }\end{array}$ & $>60$ & $\begin{array}{l}120 \\
122\end{array}$ & $\begin{array}{l}\text { IDR, AraC, ETP } \\
\text { IDR, AraC, ETP, ATRA }\end{array}$ & $\begin{array}{l}\text { Addition of ATRA to induction and consolidation chemotherapy improved CR } \\
\text { rate, EFS and OS }\end{array}$ \\
\hline $\begin{array}{l}\text { van der Holt } \\
\text { et al. [35] }\end{array}$ & $\geq 60$ & $\begin{array}{l}211 \\
208\end{array}$ & $\begin{array}{l}\text { DNR, AraC } \\
\text { DNR, AraC, PSC-833 }\end{array}$ & $\begin{array}{l}\text { Addition of the P-glycoprotein modulator PSC- } 833 \text { did not improve CR rate, } \\
\text { DFS, EFS or OS }\end{array}$ \\
\hline $\begin{array}{l}\text { Gardin et al. } \\
\text { [36] }\end{array}$ & $\geq 65$ & $\begin{array}{l}209 \\
207\end{array}$ & $\begin{array}{l}\text { DNR, AraC } \\
\text { IDR, AraC }\end{array}$ & $\begin{array}{l}\text { CR rate and OS were similar for the DNR }\left(45 \mathrm{mg} / \mathrm{m}^{2} \times 4 \text { days }\right) \text { and IDR } \\
\left(9 \mathrm{mg} / \mathrm{m}^{2} \times 4 \text { days }\right) \text { arms }\end{array}$ \\
\hline $\begin{array}{l}\text { Burnett et al. } \\
\text { [37] }\end{array}$ & $>60$ & $\begin{array}{r}103 \\
99\end{array}$ & $\begin{array}{l}\text { Low-dose AraC } \\
\text { Hydroxyurea }\end{array}$ & $\begin{array}{l}\text { Low-dose AraC resulted in higher CR rate and better OS than did hydroxyurea } \\
\text { for patients considered unfit for intensive chemotherapy }\end{array}$ \\
\hline $\begin{array}{l}\text { Pigneux } \\
\text { et al. [38] }\end{array}$ & $\geq 60$ & $\begin{array}{l}186 \\
178\end{array}$ & $\begin{array}{l}\text { IDR, AraC } \\
\text { IDR, AraC, CCNU }\end{array}$ & $\begin{array}{l}\text { Adding the alkylating agent } \mathrm{CCNU} \text { to induction therapy did not improve } \mathrm{CR} \\
\text { rate, DFS or OS }\end{array}$ \\
\hline $\begin{array}{l}\text { Latagliata } \\
\text { et al. [39] }\end{array}$ & $>60$ & $\begin{array}{l}153 \\
148\end{array}$ & $\begin{array}{l}\text { DNR, AraC } \\
\text { DNX, AraC }\end{array}$ & $\begin{array}{l}\text { Liposomal DNR did not increase CR rate, but was associated with higher rate } \\
\text { of early death and lower rate of relapse }\end{array}$ \\
\hline $\begin{array}{l}\text { Burnett et al. } \\
\text { [40] }\end{array}$ & $>60$ & 450 & $\begin{array}{l}\text { DNR }\left(35 \mathrm{mg} / \mathrm{m}^{2}\right), \operatorname{AraC}(200 \text { or } \\
\left.400 \mathrm{mg} / \mathrm{m}^{2}\right), \pm \text { PSC-833 } \\
\text { DNR }\left(50 \mathrm{mg} / \mathrm{m}^{2}\right), \operatorname{AraC}(200 \text { or } \\
\left.\quad 400 \mathrm{mg} / \mathrm{m}^{2}\right)\end{array}$ & $\begin{array}{l}\text { The doses of DNR or AraC did not correlate with CR rate or OS. Addition of } \\
\text { the P-glycoprotein modulator PSC- } 833 \text { was associated with lower CR rate } \\
\text { and shorter OS, due to excessive induction deaths }\end{array}$ \\
\hline $\begin{array}{l}\text { Lowenberg } \\
\text { et al. [41] }\end{array}$ & $\geq 60$ & $\begin{array}{l}411 \\
402\end{array}$ & $\begin{array}{l}\text { DNR }\left(45 \mathrm{mg} / \mathrm{m}^{2}\right), \text { AraC } \\
\text { DNR }\left(90 \mathrm{mg} / \mathrm{m}^{2}\right), \text { AraC }\end{array}$ & $\begin{array}{l}\text { Higher dose of DNR increased CR rate. Improvement in EFS and OS was } \\
\text { shown in the subset of patients aged } 60-65 \text { years }\end{array}$ \\
\hline $\begin{array}{r}\text { Harousseau } \\
\text { et al. [42] }\end{array}$ & $\geq 70$ & $\begin{array}{l}228 \\
229\end{array}$ & $\begin{array}{l}\text { Tipifarnib } \\
\text { Best supportive care }\end{array}$ & $\begin{array}{l}\text { The farnesyl transferase inhibitor, tipifarnib, did not result in superior OS } \\
\text { compared to that obtained with best supportive care }\end{array}$ \\
\hline $\begin{array}{l}\text { Pautas et al. } \\
\text { [43] }\end{array}$ & $50-70$ & 156 & $\begin{array}{l}\text { DNR }\left(80 \mathrm{mg} / \mathrm{m}^{2} \times 3 \text { days }\right) \text {, } \\
\text { AraC } \\
\text { IDR }\left(12 \mathrm{mg} / \mathrm{m}^{2} \times 3 \text { days }\right) \text {, } \\
\text { AraC } \\
\text { IDR }\left(12 \mathrm{mg} / \mathrm{m}^{2} \times 4 \text { days }\right) \text {, } \\
\text { AraC }\end{array}$ & $\begin{array}{l}\text { CR rate was lower for the DNR arm than for both IDR arms, without any } \\
\text { differences in relapse, EFS or OS, among the three arms }\end{array}$ \\
\hline $\begin{array}{l}\text { Cripe et al. } \\
\text { [44] }\end{array}$ & $>60$ & $\begin{array}{l}221 \\
212\end{array}$ & $\begin{array}{l}\text { DNR, AraC } \\
\text { DNR, AraC, zosuquidar }\end{array}$ & $\begin{array}{l}\text { Addition of the P-glycoprotein modulator zosuquidar did not improve CR rate } \\
\text { or OS }\end{array}$ \\
\hline $\begin{array}{l}\text { Burnett et al. } \\
\text { [45] }\end{array}$ & $\geq 60$ & $\begin{array}{l}82 \\
84\end{array}$ & $\begin{array}{l}\text { Low-dose AraC } \\
\text { Low-dose AraC, ATO }\end{array}$ & $\begin{array}{l}\text { Addition of ATO to low-dose AraC provided no benefit in terms of CR rate or } \\
\text { OS for patients considered unfit for intensive chemotherapy }\end{array}$ \\
\hline $\begin{array}{l}\text { Castaigne } \\
\text { et al. [46] }\end{array}$ & $50-70$ & $\begin{array}{l}139 \\
139\end{array}$ & $\begin{array}{l}\text { DNR, AraC } \\
\text { DNR, AraC, GO }\end{array}$ & $\begin{array}{l}\text { Addition of GO to conventional chemotherapy did not increase CR rate but } \\
\text { improved EFS, RFS and OS }\end{array}$ \\
\hline
\end{tabular}


Table 2 continued

\begin{tabular}{lllll}
\hline Study & $\begin{array}{l}\text { Age } \\
\text { (years) }\end{array}$ & $N$ & Treatments & Results \\
\hline $\begin{array}{l}\text { Wakita et al. } \\
{[47]}\end{array}$ & $65-80$ & 121 & $\begin{array}{l}\text { Set therapy } \\
\text { Individually adjusted therapy }\end{array}$ & $\begin{array}{c}\text { Extra doses of DNR and BHAC according to the bone marrow status at end of } \\
\text { induction therapy did not result in improved CR rate, RFS or OS }\end{array}$ \\
\hline
\end{tabular}

$D N R$ daunorubicin, AraC cytarabine, $V C R$ vincristine, $O S$ overall survival, $R B X$ rubidazone, $C R$ complete remission, $G M-C S F$ granulocytemacrophage colony-stimulating factor, DFS disease-free survival, MIT mitoxantrone, 6TG 6-thioguanine, ETP etoposide, RFS relapse-free survival, PSC-833 valspodar, IDR idarubicin, ATRA all-trans retinoic acid, EFS event-free survival, CCNU lomustine, DNX liposomal daunorubicin, $A T O$ arsenic trioxide, $G O$ gemtuzumab ozogamicin, $R F S$ relapse-free survival, BHAC behenoyl cytarabine

Table 3 Selected randomized studies using post-remission therapy for AML in older adults

\begin{tabular}{|c|c|c|c|c|}
\hline Study & $\begin{array}{l}\text { Age } \\
\text { (years) }\end{array}$ & $N$ & Treatments & Results \\
\hline $\begin{array}{l}\text { Lowenberg } \\
\text { et al. [30] }\end{array}$ & $>60$ & 74 & $\begin{array}{l}\text { Low-dose AraC } \\
\text { No further } \\
\text { therapy }\end{array}$ & $\begin{array}{l}\text { Eight cycles of low-dose AraC prolonged DFS, but this effect did not translate into } \\
\text { improved OS }\end{array}$ \\
\hline $\begin{array}{l}\text { Stone et al. } \\
{[48]}\end{array}$ & $\geq 60$ & $\begin{array}{l}82 \\
87\end{array}$ & $\begin{array}{l}\operatorname{AraC}(100 \mathrm{mg} / \\
\left.\mathrm{m}^{2}\right) \\
\text { MIT, } \mathrm{AraC} \\
\quad\left(500 \mathrm{mg} / \mathrm{m}^{2}\right)\end{array}$ & $\begin{array}{l}\text { There was no difference in DFS or OS between four courses of standard-dose AraC and } \\
\text { two courses of intermediate-dose AraC }\end{array}$ \\
\hline $\begin{array}{l}\text { Goldstone } \\
\text { et al. [31] }\end{array}$ & $>55$ & $\begin{array}{l}185 \\
186\end{array}$ & $\begin{array}{l}1 \text { course } \\
4 \text { courses }\end{array}$ & $\begin{array}{l}\text { After two courses of induction therapy, one course and four courses of post-remission } \\
\text { therapy yielded similar DFS and OS }\end{array}$ \\
\hline $\begin{array}{l}\text { Buchner et al. } \\
\text { [49] }\end{array}$ & $\geq 60$ & $\begin{array}{l}140 \\
157\end{array}$ & $\begin{array}{l}\text { Intensive } \\
\text { consolidation } \\
\text { Monthly } \\
\text { maintenance }\end{array}$ & $\begin{array}{l}\text { Remission duration lasted longer with monthly maintenance therapy than with a single } \\
\text { course including intermediate-dose AraC }\end{array}$ \\
\hline $\begin{array}{l}\text { Schlenk et al. } \\
\text { [50] }\end{array}$ & $>60$ & $\begin{array}{l}47 \\
49\end{array}$ & $\begin{array}{l}\text { Intensive } \\
\text { consolidation } \\
\text { Oral maintenance }\end{array}$ & $\begin{array}{l}\text { Intensive consolidation resulted in lower relapse rate and superior OS than did one-year } \\
\text { oral maintenance therapy }\end{array}$ \\
\hline $\begin{array}{l}\text { Gardin et al. } \\
{[36]}\end{array}$ & $\geq 65$ & $\begin{array}{l}82 \\
82\end{array}$ & $\begin{array}{l}\text { Intensive } \\
\text { treatment } \\
\text { Outpatient } \\
\text { treatment }\end{array}$ & $\begin{array}{l}\text { Six monthly courses of outpatient therapy yielded better DFS and OS than did a single } \\
\text { course of intensive chemotherapy }\end{array}$ \\
\hline $\begin{array}{l}\text { Pigneux et al. } \\
\text { [38] }\end{array}$ & $\geq 60$ & $\begin{array}{l}50 \\
51\end{array}$ & $\begin{array}{l}1 \text { course } \\
2 \text { courses }\end{array}$ & One course and two courses of consolidation therapy yielded similar OS \\
\hline $\begin{array}{l}\text { Burnett et al. } \\
\text { [40] }\end{array}$ & $>60$ & $\begin{array}{l}124 \\
126\end{array}$ & $\begin{array}{l}1 \text { course } \\
2 \text { courses }\end{array}$ & $\begin{array}{l}\text { After two induction courses and one consolidation course, an additional consolidation } \\
\text { course had no effect on relapse or OS }\end{array}$ \\
\hline $\begin{array}{l}\text { Pautas et al. } \\
\text { [43] }\end{array}$ & $50-70$ & $\begin{array}{l}77 \\
84\end{array}$ & $\begin{array}{l}\text { rIL-2 } \\
\text { No maintenance }\end{array}$ & $\begin{array}{l}\text { Maintenance therapy with rIL-2 for a total duration of } 12 \text { months did not result in } \\
\text { improved EFS or OS }\end{array}$ \\
\hline $\begin{array}{l}\text { Lowenberg } \\
\text { et al. [51] }\end{array}$ & $\geq 60$ & $\begin{array}{l}113 \\
119\end{array}$ & $\begin{array}{l}\text { GO } \\
\text { No post-remission } \\
\text { therapy }\end{array}$ & $\begin{array}{l}\text { Post-remission therapy with up to three cycles of GO had no effect on relapse, NRM, DFS } \\
\text { or OS }\end{array}$ \\
\hline $\begin{array}{l}\text { Wakita et al. } \\
\text { [47] }\end{array}$ & $65-80$ & $\begin{array}{l}63 \\
56\end{array}$ & $\begin{array}{l}\text { With ubenimex } \\
\text { Without } \\
\text { ubenimex }\end{array}$ & $\begin{array}{l}\text { Ubenimex, a dipeptide immunostimulator, administered during consolidation therapy } \\
\text { tended to prolong RFS but not OS }\end{array}$ \\
\hline
\end{tabular}

AraC cytarabine, DFS disease-free survival, $O S$ overall survival, MIT mitoxantrone, $r I L-2$ recombinant interleukin-2, EFS event-free survival, $G O$ gemtuzumab ozogamicin, $N R M$ non-relapse mortality, $R F S$ relapse-free survival

\section{Hematopoietic cell transplantation}

While allogeneic hematopoietic cell transplantation (HCT) offers the best chance of long-term survival for patients with poor-risk hematologic malignancies such as seen in elderly AML, it does so at the cost of higher TRM. Due to this high risk, allogeneic HCT has traditionally been limited to younger patients. However, advances in supportive care and 
the use of reduced-intensity conditioning (RIC) have extended the application of this procedure to older adults who would previously not have been candidates for myeloablative allogeneic HCT. Indeed, recent studies have demonstrated the feasibility of allogeneic HCT for selected older patients, with reported post-transplant survival rates of around $50 \%[2,3]$. A retrospective analysis of a large number of registry data showed that older age was not associated with inferior post-transplant OS [52]. In the absence of prospective studies, the efficacy of RIC-HCT for older patients remains to be verified, although accumulated evidence suggests that RIC-HCT during CR represents a reasonable therapeutic option for selected older patients. The most critical factor that interferes with the administration of allogeneic HCT could be the low CR rate attained with induction chemotherapy. Availability of a suitable donor is another obstacle for successful HCT for older patients, because their siblings are usually also elderly. The major issues for further incorporation of allogeneic HCT into treatment strategies for elderly AML that need to be addressed are improvement of the CR rate for chemotherapy, identification of a suitable donor in a timely manner, and development of transplant procedures that lead to reduced risk of post-transplant relapse and complications.

\section{Novel therapies}

Given the limitations of the intensive chemotherapy approach for AML in older adults, current clinical trials have focused on less-intensive therapies with the potential to be efficacious without impairing patients' quality of life. A growing understanding of the underlying molecular mechanisms of AML has led to development of novel agents, most of which selectively target leukemic cells, such as monoclonal antibodies, tyrosine kinase inhibitors, farnesyl transferase inhibitors, hypomethylating agents, histone deacetylase inhibitors, and others. Details about individual agents are reviewed extensively elsewhere in this issue of the journal. Development of less toxic and more targeted agents may provide treatment alternatives for a majority of older adults with AML. Given the dismal prognosis with currently available therapies and the limited tolerance for toxicity, such patients are promising candidates for such targeted therapies. The National Comprehensive Cancer Network (NCCN) panel has therefore recommended the use of investigational therapy in clinical trials for all patients over 60 years [5].

\section{Conclusions}

AML in older adults poses a significant therapeutic challenge because of the refractoriness of the disease and the frailty of the patients. These patients are biologically and clinically heterogeneous, which means that intensive chemotherapy may be beneficial for some, whereas it may be harmful for others. There is thus an urgent need to accurately identify patients likely to benefit from intensive chemotherapy. Such decisions should be individualized after systemic assessment of disease biology and patient characteristics. Currently, a number of novel agents are under investigation, most of which are selective for certain molecular targets and these involve less toxicity than do existing chemotherapeutic agents. The overall dismal prognosis for the treatment of elderly AML patients with currently available treatments constitutes a strong motivation for their participation in prospective clinical trials that aim to develop more effective and less toxic therapies.

Conflict of interest The authors declare no conflict of interest.

\section{References}

1. Estey E. Acute myeloid leukemia and myelodysplastic syndromes in older patients. J Clin Oncol. 2007;25:1908-15.

2. Dombret H, Raffoux E, Gardin C. Acute myeloid leukemia in the elderly. Semin Oncol. 2008;35:430-8.

3. Pollyea DA, Kohrt HE, Medeiros BC. Acute myeloid leukaemia in the elderly: a review. Br J Haematol. 2011;152:524-42.

4. Dohner H, Estey EH, Amadori S, Appelbaum FR, Buchner T, Burnett AK, et al. Diagnosis and management of acute myeloid leukemia in adults: recommendations from an international expert panel, on behalf of the European LeukemiaNet. Blood. 2010;115:453-74.

5. O'Donnell MR, Abboud CN, Altman J, Appelbaum FR, Coutre SE, Damon LE, et al. Acute myeloid leukemia. J Natl Compr Cancer Netw. 2011;9:280-317.

6. Pulte D, Gondos A, Brenner H. Improvements in survival of adults diagnosed with acute myeloblastic leukemia in the early 21st century. Haematologica. 2008;93:594-600.

7. Derolf AR, Kristinsson SY, Andersson TM, Landgren O, Dickman PW, Bjorkholm M. Improved patient survival for acute myeloid leukemia: a population-based study of 9729 patients diagnosed in Sweden between 1973 and 2005. Blood. 2009;113:3666-72.

8. Grimwade D, Walker H, Harrison G, Oliver F, Chatters S, Harrison $\mathrm{CJ}$, et al. The predictive value of hierarchical cytogenetic classification in older adults with acute myeloid leukemia (AML): analysis of 1065 patients entered into the United Kingdom Medical Research Council AML11 trial. Blood. 2001;98:1312-20.

9. Appelbaum FR, Gundacker H, Head DR, Slovak ML, Willman CL, Godwin JE, et al. Age and acute myeloid leukemia. Blood. 2006;107:3481-5.

10. Farag SS, Archer KJ, Mrozek K, Ruppert AS, Carroll AJ, Vardiman JW, et al. Pretreatment cytogenetics add to other prognostic factors predicting complete remission and long-term outcome in patients 60 years of age or older with acute myeloid leukemia: results from Cancer and Leukemia Group B 8461. Blood. 2006;108:63-73.

11. Leith CP, Kopecky KJ, Chen IM, Eijdems L, Slovak ML, McConnell TS, et al. Frequency and clinical significance of the expression of the multidrug resistance proteins MDR1/P- 
glycoprotein, MRP1, and LRP in acute myeloid leukemia: a Southwest Oncology Group Study. Blood. 1999;94:1086-99.

12. Menzin J, Lang K, Earle CC, Kerney D, Mallick R. The outcomes and costs of acute myeloid leukemia among the elderly. Arch Intern Med. 2002;162:1597-603.

13. Kantarjian H, O'Brien S, Cortes J, Giles F, Faderl S, Jabbour E, et al. Results of intensive chemotherapy in 998 patients age 65 years or older with acute myeloid leukemia or high-risk myelodysplastic syndrome: predictive prognostic models for outcome. Cancer. 2006;106:1090-8.

14. Frohling S, Schlenk RF, Kayser S, Morhardt M, Benner A, Dohner K, et al. Cytogenetics and age are major determinants of outcome in intensively treated acute myeloid leukemia patients older than 60 years: results from AMLSG trial AML HD98-B. Blood. 2006;108:3280-8.

15. Malfuson JV, Etienne A, Turlure $P$, de Revel $T$, Thomas $X$, Contentin N, et al. Risk factors and decision criteria for intensive chemotherapy in older patients with acute myeloid leukemia. Haematologica. 2008;93:1806-13.

16. Wheatley K, Brookes CL, Howman AJ, Goldstone AH, Milligan DW, Prentice AG, et al. Prognostic factor analysis of the survival of elderly patients with AML in the MRC AML11 and LRF AML14 trials. Br J Haematol. 2009;145:598-605.

17. Rollig C, Thiede C, Gramatzki M, Aulitzky W, Bodenstein H, Bornhauser $\mathrm{M}$, et al. A novel prognostic model in elderly patients with acute myeloid leukemia: results of 909 patients entered into the prospective AML96 trial. Blood. 2010;116:971-8.

18. Scholl S, Theuer C, Scheble V, Kunert C, Heller A, Mugge LO, et al. Clinical impact of nucleophosmin mutations and Flt3 internal tandem duplications in patients older than $60 \mathrm{yr}$ with acute myeloid leukaemia. Eur J Haematol. 2008;80:208-15.

19. Becker H, Marcucci G, Maharry K, Radmacher MD, Mrozek K, Margeson D, et al. Favorable prognostic impact of NPM1 mutations in older patients with cytogenetically normal de novo acute myeloid leukemia and associated gene- and microRNAexpression signatures: a Cancer and Leukemia Group B study. J Clin Oncol. 2010;28:596-604.

20. Whitman SP, Maharry K, Radmacher MD, Becker H, Mrozek K, Margeson D, et al. FLT3 internal tandem duplication associates with adverse outcome and gene- and microRNA-expression signatures in patients 60 years of age or older with primary cytogenetically normal acute myeloid leukemia: a Cancer and Leukemia Group B study. Blood. 2010;116:3622-6.

21. Singh H, Asali S, Werner LL, DeAngelo DJ, Ballen KK, Amrein PC, et al. Outcome of older adults with cytogenetically normal AML (CN-AML) and FLT3 mutations. Leuk Res. 2011;35:1611-5.

22. de Jonge HJ, de Bont ES, Valk PJ, Schuringa JJ, Kies M, Woolthuis CM, et al. AML at older age: age-related gene expression profiles reveal a paradoxical down-regulation of p16INK4A mRNA with prognostic significance. Blood. 2009; 114:2869-77.

23. Rao AV, Valk PJ, Metzeler KH, Acharya CR, Tuchman SA, Stevenson MM, et al. Age-specific differences in oncogenic pathway dysregulation and anthracycline sensitivity in patients with acute myeloid leukemia. J Clin Oncol. 2009;27:5580-6.

24. Giles FJ, Borthakur G, Ravandi F, Faderl S, Verstovsek S, Thomas D, et al. The haematopoietic cell transplantation comorbidity index score is predictive of early death and survival in patients over 60 years of age receiving induction therapy for acute myeloid leukaemia. Br J Haematol. 2007;136:624-7.

25. Lowenberg B, Zittoun R, Kerkhofs H, Jehn U, Abels J, Debusscher $\mathrm{L}$, et al. On the value of intensive remission-induction chemotherapy in elderly patients of $65+$ years with acute myeloid leukemia: a randomized phase III study of the European Organization for Research and Treatment of Cancer Leukemia Group. J Clin Oncol. 1989;7:1268-74.
26. Juliusson G, Antunovic P, Derolf A, Lehmann S, Mollgard L, Stockelberg D, et al. Age and acute myeloid leukemia: real world data on decision to treat and outcomes from the Swedish Acute Leukemia Registry. Blood. 2009;113:4179-87.

27. Oshima K, Takahashi W, Asano-Mori Y, Izutsu K, Takahashi $\mathrm{T}$, Arai $\mathrm{Y}$, et al. Intensive chemotherapy for elderly patients with acute myelogeneous leukemia: a propensity score analysis by the Japan Hematology and Oncology Clinical Study Group (J-HOCS). Ann Hematol. 2012 May 11. [Epub ahead of print]

28. Tilly H, Castaigne S, Bordessoule D, Casassus P, Le Prise PY, Tertian G, et al. Low-dose cytarabine versus intensive chemotherapy in the treatment of acute nonlymphocytic leukemia in the elderly. J Clin Oncol. 1990;8:272-9.

29. Lowenberg B, Suciu S, Archimbaud E, Ossenkoppele G, Verhoef GE, Vellenga E, et al. Use of recombinant GM-CSF during and after remission induction chemotherapy in patients aged 61 years and older with acute myeloid leukemia: final report of AML-11, a phase III randomized study of the Leukemia Cooperative Group of European Organisation for the Research and Treatment of Cancer and the Dutch Belgian Hemato-Oncology Cooperative Group. Blood. 1997;90:2952-61.

30. Lowenberg B, Suciu S, Archimbaud E, Haak H, Stryckmans P, de Cataldo R, et al. Mitoxantrone versus daunorubicin in inductionconsolidation chemotherapy - the value of low-dose cytarabine for maintenance of remission, and an assessment of prognostic factors in acute myeloid leukemia in the elderly: final report. European Organization for the Research and Treatment of Cancer and the Dutch-Belgian Hemato-Oncology Cooperative Hovon Group. J Clin Oncol. 1998;16:872-81.

31. Goldstone AH, Burnett AK, Wheatley K, Smith AG, Hutchinson RM, Clark RE. Attempts to improve treatment outcomes in acute myeloid leukemia (AML) in older patients: the results of the United Kingdom Medical Research Council AML11 trial. Blood. 2001;98:1302-11.

32. Anderson JE, Kopecky KJ, Willman CL, Head D, O’Donnell MR, Luthardt FW, et al. Outcome after induction chemotherapy for older patients with acute myeloid leukemia is not improved with mitoxantrone and etoposide compared to cytarabine and daunorubicin: a Southwest Oncology Group study. Blood. 2002;100:3869-76.

33. Baer MR, George SL, Dodge RK, O'Loughlin KL, Minderman $\mathrm{H}$, Caligiuri MA, et al. Phase 3 study of the multidrug resistance modulator PSC-833 in previously untreated patients 60 years of age and older with acute myeloid leukemia: Cancer and Leukemia Group B Study 9720. Blood. 2002;100:1224-32.

34. Schlenk RF, Frohling S, Hartmann F, Fischer JT, Glasmacher A, del Valle F, et al. Phase III study of all-trans retinoic acid in previously untreated patients 61 years or older with acute myeloid leukemia. Leukemia. 2004;18:1798-803.

35. van der Holt B, Lowenberg B, Burnett AK, Knauf WU, Shepherd J, Piccaluga PP, et al. The value of the MDR1 reversal agent PSC-833 in addition to daunorubicin and cytarabine in the treatment of elderly patients with previously untreated acute myeloid leukemia (AML), in relation to MDR1 status at diagnosis. Blood. 2005;106:2646-54.

36. Gardin C, Turlure P, Fagot T, Thomas X, Terre C, Contentin N, et al. Postremission treatment of elderly patients with acute myeloid leukemia in first complete remission after intensive induction chemotherapy: results of the multicenter randomized Acute Leukemia French Association (ALFA) 9803 trial. Blood. 2007;109:5129-35.

37. Burnett AK, Milligan D, Prentice AG, Goldstone AH, McMullin MF, Hills RK, et al. A comparison of low-dose cytarabine and hydroxyurea with or without all-trans retinoic acid for acute myeloid leukemia and high-risk myelodysplastic syndrome in 
patients not considered fit for intensive treatment. Cancer. 2007;109:1114-24.

38. Pigneux A, Perreau V, Jourdan E, Vey N, Dastugue N, Huguet F, et al. Adding lomustine to idarubicin and cytarabine for induction chemotherapy in older patients with acute myeloid leukemia: the BGMT 95 trial results. Haematologica. 2007;92:1327-34.

39. Latagliata R, Breccia M, Fazi P, Iacobelli S, Martinelli G, Di Raimondo F, et al. Liposomal daunorubicin versus standard daunorubicin: long term follow-up of the GIMEMA GSI 103 AMLE randomized trial in patients older than 60 years with acute myelogenous leukaemia. Br J Haematol. 2008;143:681-9.

40. Burnett AK, Milligan D, Goldstone A, Prentice A, McMullin MF, Dennis $\mathrm{M}$, et al. The impact of dose escalation and resistance modulation in older patients with acute myeloid leukaemia and high risk myelodysplastic syndrome: the results of the LRF AML14 trial. Br J Haematol. 2009;145:318-32.

41. Lowenberg B, Ossenkoppele GJ, van Putten W, Schouten HC, Graux C, Ferrant A, et al. High-dose daunorubicin in older patients with acute myeloid leukemia. N Engl J Med. 2009;361: 1235-48.

42. Harousseau JL, Martinelli G, Jedrzejczak WW, Brandwein JM, Bordessoule D, Masszi T, et al. A randomized phase 3 study of tipifarnib compared with best supportive care, including hydroxyurea, in the treatment of newly diagnosed acute myeloid leukemia in patients 70 years or older. Blood. 2009;114:1166-73.

43. Pautas C, Merabet F, Thomas X, Raffoux E, Gardin C, Corm S, et al. Randomized study of intensified anthracycline doses for induction and recombinant interleukin-2 for maintenance in patients with acute myeloid leukemia age 50 to 70 years: results of the ALFA-9801 study. J Clin Oncol. 2010;28:808-14.

44. Cripe LD, Uno H, Paietta EM, Litzow MR, Ketterling RP, Bennett JM, et al. Zosuquidar, a novel modulator of P-glycoprotein, does not improve the outcome of older patients with newly diagnosed acute myeloid leukemia: a randomized, placebo-controlled trial of the Eastern Cooperative Oncology Group 3999. Blood. 2010;116:4077-85.

45. Burnett AK, Hills RK, Hunter A, Milligan D, Kell J, Wheatley K, et al. The addition of arsenic trioxide to low-dose Ara-C in older patients with AML does not improve outcome. Leukemia. 2011;25:1122-7.
46. Castaigne S, Pautas C, Terre C, Raffoux E, Bordessoule D, Bastie JN, et al. Effect of gemtuzumab ozogamicin on survival of adult patients with de novo acute myeloid leukaemia (ALFA-0701): a randomised, open-label, phase 3 study. Lancet. 2012;379: 1508-16.

47. Wakita A, Ohtake S, Takada S, Yagasaki F, Komatsu H, Miyazaki Y, et al. Randomized comparison of fixed-schedule versus response-oriented individualized induction therapy and use of ubenimex during and after consolidation therapy for elderly patients with acute myeloid leukemia: the JALSG GML200 Study. Int J Hematol. 2012 May 26. [Epub ahead of print]

48. Stone RM, Berg DT, George SL, Dodge RK, Paciucci PA, Schulman PP, et al. Postremission therapy in older patients with de novo acute myeloid leukemia: a randomized trial comparing mitoxantrone and intermediate-dose cytarabine with standarddose cytarabine. Blood. 2001;98:548-53.

49. Buchner T, Hiddemann W, Berdel WE, Wormann B, Schoch C, Fonatsch $\mathrm{C}$, et al. 6-Thioguanine, cytarabine, and daunorubicin (TAD) and high-dose cytarabine and mitoxantrone (HAM) for induction, TAD for consolidation, and either prolonged maintenance by reduced monthly TAD or TAD-HAM-TAD and one course of intensive consolidation by sequential HAM in adult patients at all ages with de novo acute myeloid leukemia (AML): a randomized trial of the German AML Cooperative Group. J Clin Oncol. 2003;21:4496-504.

50. Schlenk RF, Frohling S, Hartmann F, Fischer JT, Glasmacher A, Del Valle $\mathrm{F}$, et al. Intensive consolidation versus oral maintenance therapy in patients 61 years or older with acute myeloid leukemia in first remission: results of second randomization of the AML HD98-B treatment Trial. Leukemia. 2006;20:748-50.

51. Lowenberg B, Beck J, Graux C, van Putten W, Schouten HC, Verdonck LF, et al. Gemtuzumab ozogamicin as postremission treatment in AML at 60 years of age or more: results of a multicenter phase 3 study. Blood. 2010;115:2586-91.

52. McClune BL, Weisdorf DJ, Pedersen TL, Tunes da Silva G, Tallman MS, Sierra J, et al. Effect of age on outcome of reducedintensity hematopoietic cell transplantation for older patients with acute myeloid leukemia in first complete remission or with myelodysplastic syndrome. J Clin Oncol. 2010;28:1878-87. 